\title{
Analysis of the Relationship between Automaker and Systemist in an Industrial Condominium of the Automotive Industry
}

\author{
Mário Sacomano Neto \\ Professor at Methodist University of Piracicaba (UNIMEP) \\ msacomano@unimep.br \\ Sílvio R. I. Pires \\ Professor at Methodist University of Piracicaba (UNIMEP) \\ sripires@unimep.br
}

\begin{abstract}
The implementation of industrial condominiums in Brazil's automotive industry introduced a new standard for the relationship between automakers and auto parts suppliers. High levels of outsourcing, long-term contracts, integrative agreements, coproduction of components, exchanges of specific resources, and intensive interchange of information characterize the automaker's relationship with suppliers in these new arrangements. This paper analyzes the relationship between an automaker, constituted in the form of an industrial condominium, and a systemist supplier operating inside the automaker's plant, exploring the impacts and innovations in the way production is organized and in how the supplier's performance is measured. The findings reveal the transfer of added value from the automaker to the systemist supplier and a high degree of integration of logistics and production between companies.
\end{abstract}

KEYWORDS: Supply chain management; supply chain structure and relationships; organization of production and performance.

\section{INTRODUCTION}

Brazil's automotive industry has attained reasonable performance as a world-class player in the assembly of automobiles. In 2007, 2.97 million units were assembled. This result is $13.9 \%$ higher than that achieved in 2006 and represents the best result of the sector, according to ANFAVEA (National Association of Motor Vehicle Manufacturers; Brazil) (2008). In 2007, Brazil ranked as the world's sixth largest vehicle manufacturer, outranking France and Spain. The world's largest producer in 2007 was Japan, followed by the United States, China, Germany and South Korea (ANFAVEA, 2008). Specialists point to the rapid rise of emergent markets among the world's largest vehicle manufacturers, especially the case of China (LUNG, 2000).

Since the mid-1990s, several productive arrangements have been implemented in Brazil's automotive sector, among them the modular consortium and industrial condominiums. These arrangements are characterized by high levels of outsourcing, long- term contracts, integrative agreements, coproduction of components, exchanges of specific resources, information interchange, and support to suppliers. These practices have led to substantial modifications in the relationship and in the measurement of performance among the actors in the supply chain (MCCORMACK, LADEIRA \& OLIVEIRA, 2008; LEE, KWON \& SEVERENCE, 2007; FYNE, VOSS \& VÚRCA, 2005).

The relationship standard between automakers and suppliers is a central aspect of the new strategies of the automotive sector and it supports the process of internationalization of automakers and suppliers. Cooperation and partnerships with suppliers are also forms of capturing resources (GULATI, 1999; GNYAWALI \& MADHAVAN, 2001) and of minimizing uncertainties (FRIEDBERG \& NEVILLE, 1999), which are such prominent characteristics for the insertion of companies into the global market. Automakers use these strategies to implement new plants in emergent markets. 
Brazil is an attractive country due to the rapid growth of the automotive market, lower cost production units, accelerated growth of driving rates (LUNG, 2000), and privileged fields for new organizational and labor experiments (HUMPHREY et al., 2000). However, the vulnerability of these markets requires that automakers adopt adaptive strategies that are able to reach domestic and export markets, allowing for economies of scale and scope (LUNG, 2000). To this end, automakers simplify products, reduce the number of platforms, adhere to new forms of labor relations, and, principally, reduce costs through partnerships with suppliers. This fact has modified the relationship standard and the level of integration among these companies.

A primary consequence of this change is the series of responsibilities attributed to auto parts suppliers (HUMPHREY et al., 2000), especially through the activities introduced by follow sourcing, global sourcing and by the modularization of production. Other activities that have been "attributed" or "delegated" to suppliers encompass research and development, quality, new investments, new technologies and supply chain management.

The demands of automakers on first tier suppliers range from design capability and manufacturing excellence to product delivery (HUMPHREY et al., 2000). These authors highlight three trends in the change of the relationship between automakers and auto parts suppliers: first - greater supplier responsibility for design; second - a trend for the supply of complete functions (systems, subsystems or modules); and third - automakers are standardizing their platforms among their sister companies in the different markets.

This new relationship standard between automakers and suppliers in Brazil's automotive sector motivated the present research, which was conducted by means of interviews with five executives from the areas of production and logistics at the automaker and a director of production at the systemist supplier. The study of the relationship between automaker and systemist constitutes the central theme for an understanding of strategies and the new configuration of the automotive sector in Brazil. Our efforts focused on gaining an insight of the reflexes of this new relationship standard on production and logistics practices and on measures of performance.

To achieve the proposed objective, this paper discusses the dynamics of the structure and the relations in the context of supply chain management, the configurations of the world's and Brazil's automotive industry, the research methodology, the companies of this study, the relationship among companies in the industrial condominium, the impacts on product planning, production, supply and measurement of performance in the chain, and our final conclusions.

\section{STRUCTURE AND RELATIONSHIPS IN THE SUPPLY CHAIN}

Structure and relationships are central elements in the analysis of supply chains (LAMBERT et al., 1998). However, before understanding the structure and relationships in the chain, one must grasp the core concepts of supply chain management. Supply Chain Management - SCM is originating from the literature about logistics, specifically the issues of purchasing and administration of stocks (TRIENEKENS, 1999). The council of Logistics Management defines logistics as "a part of the supply chain management that plans, implements and effectively controls flows, product stocks, services and correlated information, from the point of origin to the point of consumption, with the objective of meeting the clients' needs" (LAMBERT et al., 1998 p.3). The authors point out that logistics has a functional role involving the flows of information and materials in the supply chain.

SCM involves interorganizational integration and coordination from suppliers to final clients, the integration of many distinct organizations, also the presence of bidirectional flows of products and information. Lastly, SCM seeks to value the client with the appropriate use of resources and also to build competitive advantages in the supply chain. Pires \& Carrretero Diaz (2007, p. 25) emphasizes that the "SC is a network of autonomous or semi-autonomous companies that are effectively responsible for obtainment, production and release of a given product and/or service to the final client."

Listed below are some of the assumptions of SCM found in the literature about supply chain management: competition among chains and no longer between isolated companies (CHRISTOPHER, 1998); alignment of competitive strategies among the companies participating in the chain (BAUM \& DUTTON, 1996); coordination and planning of the activities and processes among the companies that make up the chain (COOPER et al., 1997); alignment of the business processes and integration of functions in an intra- and intercompany process (COOPER et al., 
1997); existence of a bi-directional flow of products (materials and services) and information among the companies belonging to the chain and establishment of cooperative relationships among the companies involved (PRAHINSKI \& BENTON, 2004); existence of long-term commitments between suppliers and clients (CHRISTOPHER, 1998); joint investments in research and development and co-design. supplier involvement in the product fabrication process (PIRES \& CARRETERO DÍAZ, 2007); electronic data exchange (LAUER, 2000; SANCHES \& PERES, 2003; KOUDAL \& WELLENER, 2003); trust between clients and suppliers in the chain (SVENSSONS, 2001), among several other issues widely discussed in the literature on the theme.

In this sense, the structure of the chain is understood as the set of relationships upstream and downstream of the chain, and the relationships - cooperative or not, begin to represent essential aspects for the chain's management and, hence, for the improvement of the levels of stocks and services rendered to the client. Lambert et al. (1998) cite three interrelated elements: the structure, the process and components for the SCM. The structure of the chain involves actors, the vertical structure, the horizontal structure and horizontal position of the organizations of the chain of suppliers. Business structures are strucrures of activities designed to add value to the end product. The management of the chain's components involves managerial activities in which the business processes are integrated and managed along the chain.

The format of the supply chain and logistics structure can be a competitive advantage (LAMBERT et al. 1998). However, structuring and managing a set of relationships has become an extremely complex strategic issue. Uzzi (1997) reflects on the consequenced of adopting different supply chain configuratios, as illustrated in Figure 1. Each chain is composed of a contractor (the focal company) connected to the first and second tier suppliers. The thick lines represent a higher degree of reciprocity, cooperation, trust, exchange of refined information, etc. The tenuous lines indicate the market relationships (arm's length), of supplier selection criteria based on the best price.

If an organization is deeply inolved in cooperative relationships with a few suppliers and clients, it becomes highly dependent (overembedded chain) on these actors, making it difficult for the focal company to adapt to the competitive dynamics and to innovations (UZZI, 1997).

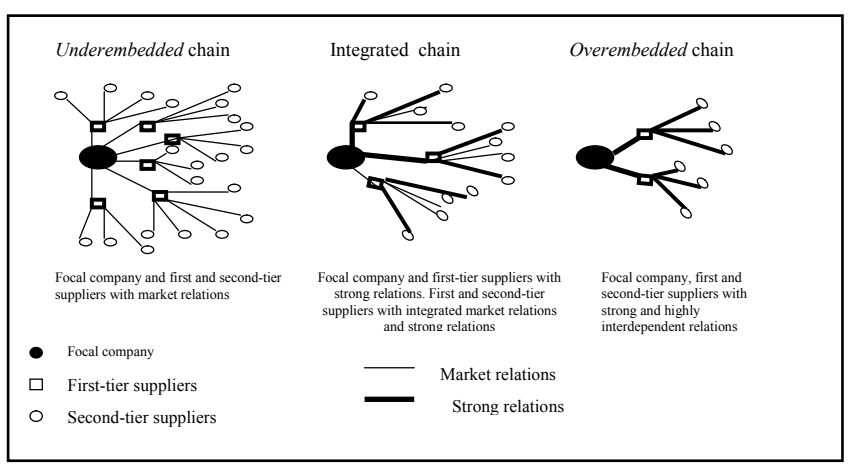

Figure 1 - Types of chain structures and their respective links (Source: UZZI, 1997)

If an organization has market relations solely inside the chain, which the author calls an underembedded chain, the business and relationships among companies are conducted based on the criterion of price, with little cooperation, trust and integration, i.e., they are strictly market relations.

The integrated chain, according to Uzzi (1997), would be the most suitable way to struture a supplier chain, for it combines: 1) cooperative relationships with high interdependence and refined exchanges, and 2) market relations with a cost-based criterion. In the integrated chain there is no exclusive dependence on a few suppliers and there is also the possibility of receiving non-redundant information. As Uzzi (1997) points out, the degree in which relations of cooperation and little cooperation facilitate transactions depends on the quality of the connections, the position and the key companies in the chain. For this reason, understanding the dynamics of the structure of the chain is essential in order to compete.

A contribution concerning relationships in the supply chain was presented by Lambert et al. (1998). The authors mentioned four types of connections in supply chains: managed, monitored, non-managed and indirect connections. Figure 2 illustrated the types of connections in supply chains.

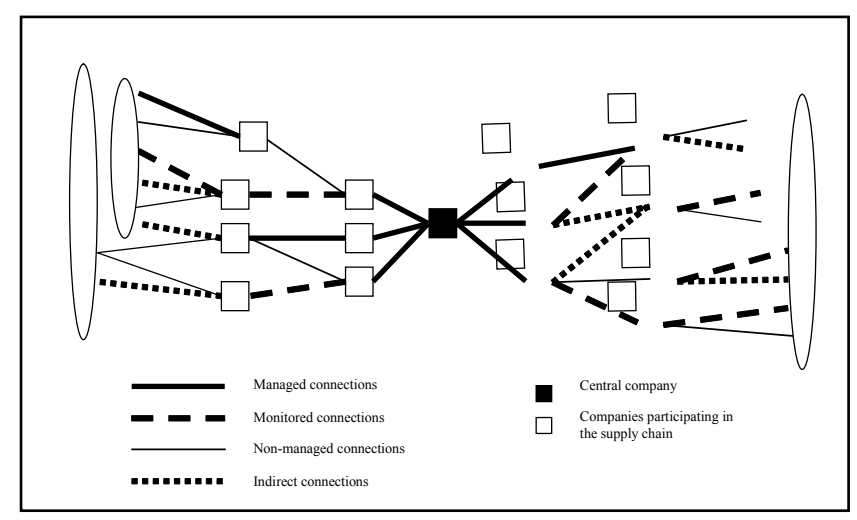


Managed connections are those that occur when the central company integrates its processes with clients and suppliers through collaboration. Monitored connections are forged when a central company monitors and audits the supply chain processes. Nonmanaged connections occur when the central company does not monitor the participating actors due to the mutual trust existing between the actors. Indirect connections are the ones that influence the central company indirectly in the absence of a relationship with the actor in question. Every supply chain varies according to the diverse types of connections existing in it. The different types of connection can influence the type of information, the mechanisms of performance control, and the forms of production management, among various other aspects.

Several studies have found that more cooperative relations among companies in the chain lead to gains (GHOSH \& FEDOROWICZ, 2008; SOOSAY, HYLAND \& FERRER, 2008; HADAYA \& CASSIVI, 2007).

Supplier relations management is a central process in the model of Lambert et al. (1998). Companies should develop partnerships with key suppliers to underpin the management of manufacturing flow, product development and commercialization (PIRES \& CARRETERO DÍAZ, 2007).

The structural and relational dimensions in the chain help one to understand the nature of relationships among productive actors and to design new supply and distribution channels. Supply chain managers need to map the participating actors, identify the critical connections to be monitored, and establish, or not, cooperative bonds among the actors.

As Podolny (1994) asserted, market uncertain ties and failures lead organizations to adopt a more cooperative orientation in search of partnerships and long-term relationships. Increasingly, the actors of the automotive sector have been using this orientation as a facilitating element in exchanges and as a principle for selecting exclusive partners. This process will be analyzed within the context of the Brazilian automotive industry.

\section{CONFIGURATIONS OF THE WORLDWIDE AND BRAZILIAN AUTOMOTIVE INDUSTRY}

The last few years have seen an intensification of the internationalization of the automotive industry, a process that represents one of the core strategies of automakers. Internationalization, geographic distribution and international division of labor represent primary themes for studies of the sector, in view of the stabilization of vehicle production and sales in the markets of the triad: United States, Japan and Europe, according to Humphrey et al. (2000). As a result, there has been a significant change in the role of regional markets, as in the case of the Mercosur.

Currently, the sector is expanding its productive structures in a large part of the world's countries. According to Humphrey et al. (2000), the dynamic of the automotive sector is divided principally into three markets: protected autonomous markets (PAMs), integrated peripheral markets (IPMs), and emerging regional markets (ERMs). The first is composed of countries that protect themselves against outside competition through domestic markets, such as India, China and Malaysia. The second comprises the countries located close to large markets, such as Mexico, the Czech Republic, Hungary and Poland. The third market is composed of countries inserted in emergent blocks, such as Brazil and Argentina, Russia and Turkey. Although these markets represent "new spaces" of action for automakers and auto parts suppliers, the internationalization of the automotive sector is not a homogeneous process.

Although the expansion of the automotive industry has a global character, the realities and peculiarities of each market call into question the existence of single production models, as a result of the legitimation of the best management practices. Volpato (2002) points out that the internationalization of the automotive sector has two extremes: on the one hand, a significant standardization of organizational forms and of decision-making processes originating from headquarter companies and, on the other, localization and adaptation to each regional context. Cultural, social, political and economic differences require different forms of implementation and diffusion of productive systems, leading, according to Boyer et al. (1998), to a process of hybridization. These authors believe that the diffusion of productive systems depends, on its consolidation, on a series of economic, social and historical aspects.

Emerging markets, such as the Brazilian market, are considered attractive due to the following factors: rapid growth of the vehicle market, production units in lower-cost locations, accelerated growth of driving rates (LUNG, 2000), and privileged fields for 
new organizational and labor experiments (HUMPHREY et al., 2000).

The transformations of structural foundations of Brazil's automotive sector open up a fast field of research, which involves new production models. The large number of mergers, acquisitions, co-production, consortiums, franchising, strategic alliances, long-term contracts and joint ventures demonstrate the sector's dynamic and complex characteristics. In recent years, several new organizational arrangements have been implemented in Brazil's automotive sector, among them the modular consortium and the industrial condominium. These new arrangements are marked by a high degree of outsourcing, longterm contracts, integrative agreements, component co-production, exchange of specific assets, information transfer, and support to suppliers. These arrangements modify the relationship standard of automakers with auto parts suppliers.

The strategic change in automakers is also related with a greater rationalization in the relations with auto parts suppliers. Economic, technological and market uncertainties lead to the establishment of cooperative agreements with suppliers (KNIGHT, 1998). This fact has given first tier suppliers highstatus positions and, hence, new roles to play in the supply chain of Brazil's automotive industry.

These changes have led to two consequences for the auto parts sector: 1- a significant increase in automaker demands concerning quality, just-in-time deliveries, global sourcing, follow sourcing, product development, co-design, and financial and technological capacitation (CARVALHO et al. 2000); and 2- concentration of the auto parts suppliers in the hands of large international groups and a deep denationalization of the sector.

The introduction of new productive arrangements the modular consortium and industrial condominium - have placed Brazil's automotive sector on the map in the discussion of industrial models (HUMPHREY et al., 2000). The Brazilian automotive sector is becoming a model for several countries, including the most industrialized nations, where the headquarters of the companies that have manufacturing units in Brazil are located.

\section{RESEARCH METHODOLOGY}

This research is classified as exploratory, descriptive, qualitative and case study-based.
Table 1 classifies the research methodology.

\begin{tabular}{|l|l|}
\hline Subject & Methodology \\
\hline Objective & $\begin{array}{l}\text { Exploratory and descriptive } \\
\text { research - seeks to understand } \\
\text { the relationship between the } \\
\text { automaker and the systemist } \\
\text { supplier }\end{array}$ \\
\hline Approach & $\begin{array}{l}\text { Qualitative - allows for an } \\
\text { understanding of the objective } \\
\text { and subjective elements of the } \\
\text { relationship }\end{array}$ \\
\hline Method & $\begin{array}{l}\text { Case studies - the automaker and } \\
\text { the systemist supplier and their } \\
\text { relationship were researched }\end{array}$ \\
\hline technique & $\begin{array}{l}\text { Interviews with semi-structured } \\
\text { script - these were held with 5 } \\
\text { executives at the automaker and } \\
\text { one at the systemist supplier - } \\
\text { these interviews allow for an } \\
\text { explanation of the “world view" of } \\
\text { the interviewee }\end{array}$ \\
\hline
\end{tabular}

The exploratory research approach is suitable when: a) the situations analyzed are contemporary, encompassing and complex; $b$ ) the focus falls more strongly on understanding rather than on quantifying the facts; and c) there are several methodological sources to uncover the facts and applicable to situations in which there is no control over the events/behaviors of the facts/people involved in the research (YIN, 1994). This research is exploratory and descriptive in as much as it examines the relationship between automaker and systemist and the impacts of this relationship on the forms of production organization and on the measures of supplier performance.

Qualitative research involves meaning, relationships and people for an understanding of the phenomena. According to Chizzotti (1999, p.79), "the qualitative approach starts from the premise that there is a dynamic relationship between the real world and the observer (...). The observer inasmuch integral part of the process of knowledge and interprets the phenomena, giving them meaning." Qualitative research allows for a deeper analysis of the research object. The study does not allow for generalizations, but makes a more subjective analysis of the relationship between automaker and systemist supplier. 
The case studies involved a vehicle manufacturer and a supplier of automotive systems (the systemist). According to Yin (1994), case studies are indicated in three situations: 1) when the case study represents an opportunity to confirm, contest or extend a theory; 2) when it is an extreme and rare case; and 3) when it involves something revealing, a unique opportunity for analyzing an inaccessible phenomenon. The present research is related with situation 3 , because it studies very particular and specific aspects of the relationship between the automaker and the systemist within the context of an industrial condominium. That is the main reason for the choice of these companies for this research.

In addition to a review of bibliographic material and observation, data were collected through interviews in loco with five executives from the areas of logistics, purchasing and production at the automaker and one executive of the systemist supplier. The semistructured script for collecting the data involved a study of the supply chain structure, the relationship between companies, performance measurements, logistics, and production planning and control. The semi-structured script allows the interviewee to describe his "world view" and gives greater depth to any given topic. In this research, we attempted to combine closed and objective information with more ample and subjective information.

The interviews and non-participant observation, in which the researcher does not join the observed group, complemented each other in the data collection process. The visit and act of interviewing provide the researcher with a variety of relevant information. The language, stories, behavior, and treatment are some of the aspects observed in the researcher's contact with the interviewees. The case study was conducted during the second semester of 2007 and the first three months of 2008.

\section{COMPANIES STUDIED}

A set of relevant characteristics and/or information of the studied companies is briefly described below.

\subsection{THE AUTOMAKER}

The oldest automaker in the country was established in 1957, in the city of São Bernardo do Campo. This plant represents one of the icons of the automotive industry and of Brazilian industrialization. In the end of 2007, this manufacturing unit employed approximately 20,545 people (automaker: 15,000; third parties: 5,545 ) and more than a thousand engineers at its Engineering Center. The São Bernardo do Campo plant has a production capacity of 1,600 vehicles/day.

In 2002, the São Bernardo plant was restructured to transform it into an industrial condominium. As Pires \& Carretero Díaz (2007) explain, in the industrial condominium the suppliers are physically installed next to the automaker. The industrial condominium is composed of 8 companies that supply parts in sequence and in real time to the automaker. Installed in this condominium are the suppliers of tires, wheels, door accessories, cables, chassis components, fuel tank, exhaust pipes, brake and accelerator pedals, instrument panels, and interior car door panels. The modules and systems manufactured by the suppliers are transported and sequenced according to the automaker's production schedule, operating according to the just-in-sequence system.

According to data published by Automotive Business (2005), the company invested $R \$ 2$ billion in a highly automated and modern structure. Laser welding, robotized framework islands, automated paint line, the use of palmtops to control production in real time, assembly by a modular system, and car body transporting devices that adapt to the height of the worker are some of the improvements and innovations implemented in the new plant.

\subsection{THE SYSTEMIST}

The systemist supplier (SS) was installed inside the automaker's plant. The supplier belongs to a German group of the automotive sector, supplying parts and systems for car bodies, chassis and engines (powertrain systems). At the end of 2007, the group to which the systemist belongs had 140 plants in 17 countries and employed 184,000 people. In addition to the automotive sector, the group acts within the steel, elevators, technologies and services sectors. In Brazil, the group has 22 subsidiaries and employs approximately 9,000 people. When the negotiations to set up the industrial condominium began, the automaker asked the SS for two estimates, one corresponding to the plant located outside and the other for the plant located on the automaker's premises. The supplier made a detailed study of its needs to present to the automaker. The SS was thus able to reduce the cost of its participation to the automaker cost by $15 \%$ simply by being located on the premises of the condominium. The logistic cost and the syn- 
ergy between the supplier and the automaker were identified as the principal factor for the cost reduction. Other benefits are energy, water, restaurants, buildings, and security, among other aspects offered by the automaker. "However, the main factor responsible is logistics since, if we were located outside, we would have to produce, transport by truck, unload, sequence the parts and deliver them to the automaker," all of which generates costs, according to the SS manager.

\section{RELATIONSHIPS BETWEEN COMPANIES IN THE INDUSTRIAL CONDOMINIUM}

Intense consolidation with the supplier base in the automotive sector has been observed in several countries, and in Brazil it was no different. The consolidation of the supplier base led to a significant structural change in the automotive chain. The large transnationals began buying up national companies and placing themselves as first-tier suppliers in the chain (SALERNO, et al. 2003). This structural change, whereby the automaker maintains relations with fewer suppliers, affected the relationship standard and the level of integration between suppliers and automakers.

The relationship between automaker and systemist can be classified as highly managed and integrated, according to the classification proposed by Lambert at al. (1998). Integration is a central aspect in the relationship between automaker and systemist. Pires \& Carretero Díaz (2007) present different levels of relationships among companies, from the least to the most integrated (commercial relations, non-contractual agreements, licence agreements, alliances, partnerships, joint ventures and vertical integration). Partnerships and joint ventures represent relationships with high levels of integration in the chain. In this classification, the relationship involves a marked level of collaboration, alignment of objectives, and integration of processes and information.

The joint venture established between the SS and the automaker indicates a high degree of integration and complementarity of competencies. The industrial manager of the SS stated that "integration, cost reduction and collective facilitators" are the main reasons for being in the condominium. This gives the SS access to resources, information and systems that other suppliers do not have: real levels of demand, changes in products and technologies, and other valuable information and know-how. The industrial manager of the SS also highlighted a technological partnership between the group to which the SS belongs and the automaker in Germany for the fabrication of modules similar to those manufactured in Brazil. All the technology the SS uses here in Brazil also comes from the know-how generated jointly in Germany with the automaker of this research. Thus, the relations between the SS and the automaker display a high level of sharing of knowledge relating to component production and development.

Another point cited by the interviewee is the fact, because the SS is right beside the assembly line, "you can go there and solve any problem of logistics, quality or production." The SS and the automaker also have daily meetings to deal with operational questions of logistics and production. The frequency of contact is very high, enabling them to operate with low levels of stocks and a high level of integration for the solution of problems. These contacts create bonds of trust between the companies, rendering the system even more efficient, as indicated by the findings of the study by Morris et al. (2004), who point out that modularization does not refer solely to technology but also to organizational and social relationships between companies. This format of supply chain structure, which privileges a high degree of reciprocity, trust, and exchange of refined information, is worldwide trend in the automotive sector. The new relationship structure facilitates management of the supply chain in several aspects, such as stocks, information flows, and client demands, allowing for coordination and planning of the activities and processes between the companies that make up the chain.

This research confirmed several assumptions set forth in the literature about supply chain management in the relations studied here, such as the establishment of cooperative relationships among companies involved; long-term commitment between suppliers and clients; joint investments in research and development and in co-design; supplier involvement in the product manufacturing process; and the electronic exchange of data. These elements favor high levels of integration, coordination of work methods, and transfer of added value to the companies. Evidently, one cannot generalize this finding to other links in the chain. The relationships with non-systemist suppliers are not characterized by the same level of integration and complementarity of competencies, as reported by Pires \& Carretero Díaz (2007). 
The high degree of integration by systemist companies is reflected in the practices and innovations in the condominium. Some innovations involve the use of modules, just-in-sequence deliveries, the Kanban system, EDI (electronic data interchange), crossdocking, logistic consolidator, the poka-yoke system, and the joint venture between the automaker and the SS. Some of these innovations will be described below.

The SS produces in a sequenced form. When the vehicle leaves the automaker's paint shop, it must be assembled. The automaker sends an electronic signal (label) placed at the beginning of the systemists' production line. The label contains the number of the vehicles, the sequential number, and the model of the module to be assembled. The SS copies the label and begins production. The production line tells the operators, by means of lights (poka-yokes), what parts are needed to assemble that module. At the end of the line, the SS attaches the automaker's label to the parts, which are then sent in sequency to the automaker's assembly line. All the systemists of the industrial condominium are responsible for sequencing. This sequencing is also a requirement for some outside suppliers.

One fact clearly illustrates the integration between automaker and SS. At the moment the automaker sends the labels indicating the vehicles to be assembled, the SS has only 1 hour and 30 minutes to send and sequence the parts according to the automaker's production plan. That is why there is a high investment in preventive maintenance (planned). The industrial manager had the following to say about sequencing and short-term deliveries: "it generates a lot of stress... and the line cannot be stopped." This requires from clients and suppliers a high level of intercompany coordination in the management of stocks, demand and productive capacity.

\section{PRODUCT, PRODUCTION AND SUPPLY MAN- AGEMENT}

The automaker's production is organized into three macro-processes, involving the product planning system, production planning and supply of the assembly line. The product planning activities begin with an alteration in drawings or with a new vehicle design (new designs or modifications of existing designs). This phase is marked by numerous meetings and teams to discuss the new design or vehicle design changes, such as: types of parts, financial as- pects, development of tooling and supplier qualification. The initial phase consists of product development and production planning with the key suppliers.

During production planning the automaker selects all the suppliers. For purposes of the architecture of raw materials, the suppliers have a visibility of 6 months of the schedule through releases. Ten weeks before production begins there is still a flexible period (up to the $8^{\text {th }}$ week) until the schedule is frozen in the last two weeks. The suppliers have access to these phases to suggest and introduce changes in the vehicle. After this phase comes the planning phase of how many cars will be produced (monthly, weekly and daily). The entire production is managed by the Manufacturing Information System (MIS), which stores and coordinates the orders from dealers and then determines the models, versions to be manufactured. The system also sends the parts orders to the suppliers to supply the line.

Supply of the production line also has several innovations. The automaker has about 400 outside suppliers. To supply the line, the plant operates by the milk run and Kanban systems with outside suppliers. A logistic consolidator is hired to collect raw materials to supply the plant's production line. The Kanban system is applied for large and expensive parts. Both the milk run and Kanban systems reduce logistics costs and stock, as well as the number of trucks circulating on the plant's premises. The EDI (Electronic Data Interchange) system is being implemented with some suppliers and with others through the Internet.

The above phase is followed by the supply operation, which has to be planned from the point of use (packaging, ergonomics, transportation, supply flow, weight, warehouse, installations, information system, type of vehicle, FIFO and LIFO control) in order to avoid unnecessary warehousing. The plant has 22 warehouses to make raw materials available at the moment of assembly. The placement of material at the point of use is called cross-docking in the literature (PIRES \& CARRETERO DÍAZ, 2007).

All the production of the SS is made to order. There is some safety stock to cover eventual problems, which the automaker's production line for the SS takes advantage of to make a small buffer stock of the most frequently used parts. Due to the need for low stocks, production and supply planning play a significant role in reducing logistics and transport costs. 


\section{SUPPLY CHAIN PERFORMANCE MEASURES}

We found no single system for dealing with supply chain performance measures. The automaker itself has an internal system that includes some supply chain performance measures. It was found that companies have internal systems for measuring performance that extend to supply chains.

The automaker measures performance using KPIs (Key Performance Indicators) that encompass all the internal areas of the company, from departments to people. The criteria are based on corporate objectives of highest added value for specific areas to individual sectors, directorates, departments and manufacturing. The performance criteria are indicated by a color code (green, yellow and red) with well-defined limits of control. These numbers are consolidated by the finance area (controller), which determines the results of the indicators, not only financial but also of other areas. The results are similar to those presented by Gulledge \& Chavusholu (2007).

Some of the logistics performance measures are detailed down to the supplier level. One of the logistics performance measures is cripple, which measures the number of missing units and may indicate supply chain-related issues, e.g., "it indicates if the car is lacking parts and measures failures of the entire supply chain", explained one of the automaker's logistics managers. Indirectly, the KPIs end up reflecting on the suppliers. The reflexes of the KPIs on the systemists are discussed by executives in daily meetings, where preventive and corrective actions are decided.

Logistics has 10 sets of indicators: percentage of lost production, bill of materials, volumes of rejects, cripple (number of missing units/incomplete vehicles), inventory levels, deliveries of replacement parts, overtime (payment of direct or monthly personnel), logistic cost (purchase of materials/supplies), overhead, and inventory volume and fidelity. These sets are specifically for logistics. Each supervisor and employee has their own KPI chart and criteria that add value to their area.

According to the interviewees at the automaker, the suppliers are evaluated constantly based on at least three major performance criteria:

Logistics - operational aspects (packaging, type of delivery, innovations, new systems, and especially faithfulness in fulfilling the program,
Engineering - development potential (software, technical knowledge),

Quality - a system that ensures the quality of the process (internal process, means of control, calibration of tooling, maintenance).

For new projects, the purchasing area indicates the suppliers that are qualified to supply. The choice of suppliers involves identifying the best price and selecting three suppliers, whereupon the proposal is submitted to the other areas. The area of quality may veto the choice, claiming that the supplier is unqualified. If an area vetoes a supplier, the supplier will need to have a very efficient action plan.

The automaker also has a supplier evaluation system which is multifunctional, involving logistics, engineering, quality, finance and commercial. The forums for defining suppliers are also multifunctional. Both systems work somewhat like external supplier performance measure systems.

The suppliers also have internal performance measure systems that extend to external measures. The SS has several performance measures, such as physical sales, customer complaints, field failures, client assembly line stoppage, average failure time, waste and scrap control, material blocked by suppliers, product audits, and maintenance control. The criteria related directly to the automaker first supply chain tier are customer complaints and client assembly line stoppage. According to the interviewee, the SS has much stricter internal performance measures than those used by the automaker to measure supplier performance. What the automaker really controls is line stoppage and SS quality.

\section{FINAL REMARKS}

The implementation of the industrial condominium brought major changes in the automaker's relationship with auto parts suppliers, particularly with the systemists. As Doran (2004) explains, in the modular system there is a transfer of added value from the automaker to first-tier suppliers, especially to systemists. Morris et al. (2004) stated that the systemists gives rise to mutual development between automaker and suppliers in accepting work methods, standard procedures, rules, documents and methods of communication. This characteristic renders the system mode interactive than impository, "in other words, modularization does not refer solely to technology but also to organizational and social re- 
lationships between companies"' (Morris et al., 2004, p. 130).

Simplification of the supply system was an issue brought up by the automaker's interviewees. In the words of the automaker's logistics manager, "if we did not have the systems, we might have 40,000 items rather than 25,000 to manage, so the systemist manages a very large parcel of items" with high added value. The modular design is used in Mercedes-Benz's "Smart" design. While a typical Mercedes-Benz car requires 100 suppliers, the "Smart" model uses 25 systemists. The benefits to the automaker are reduced risks, investments and costs, according to Doran (2004). For the systemists there is an increase in responsibilities and a high degree of involvement in product and process development. Pires (1998) adds the factor of opportunity for the supplier to develop new competencies by becoming a systemist, as was the case of modular consortium suppliers.

The items supplied by the SS are items with high added value for the automaker and present vehicle safety characteristics. The SS is physically next to the automaker and presents high levels of efficiency, as indicated during the interviews. All product and process development, production and supply are carried out in an integrated way between the SS and the automaker. This finding is consistent with that of Doran (2004), who points out that there is a considerable transfer of added value from the automaker to the modulists, who must have a culture of quality, supply items at low cost, have research and development capabilities, achieve global presence and the capacity to develop modular solutions for automakers.

The automaker consolidated its supplier base into a small number of partners, going from multiple suppliers to single suppliers. However, the systemists must present high levels of performance, for if the systemist allows the assembly to stop, the cost is very high (the value of the cost of the lost cars). Therefore, the SS has invested heavily in maintenance, daily meetings and several performance measures to ensure its supply to the automaker. In the words of one of the automaker's managers, "It is much easier to measure performance issues with the systemists, since they cause us infinitely fewer problems, not least because we scrutinize them more closely because they are in the plant. Sometimes it is much more troublesome to solve a problem of a glove compartment screw than that of a systemist."
Considering the types of connections presented by Lambert et al. (1998), the relations between the SS and the automaker are marked by a high degree of monitoring. According to the SS manager, each day production line leaders go to the automaker to check if there is any problem. "These relations produce good results... ...that is the advantage of being in here... ...our employee goes directly to the person who receives our module, so this communication is very intensive." The connections with the SS are managed and strongly monitored by the automaker. This finding is in line with Mchung, Humphreys \& Mclvor (2003), who point out that cooperation is greater the greater the participation in the cost of the part supplied at the end product.

This research contributes to show how strategic bonds in the supply chain receive higher investments in innovations and monitoring. This fact indicates that the traditional relationships are limited when it comes to generating collective gains. Partnerships and cooperation have proved to be important elements in the configuration and formation of supply chains in the automotive sector. Relationships of this type imply collective gains for actors with high positions in the structure of the chain. This position of prominence is, in large part, occupied by first-tier suppliers and in large part by transnationals.

One point noted here is that the higher the strategic value and the asset specificity of the item supplied the greater the possibilities of expanding partnerships in the search for mutual gains. At the same time, the auto parts suppliers assume greater responsibilities and the automakers make greater demands.

This study has limitations, the first of which refers to sampling. The case study at only one company cannot lead to generalizations to other automakersupplier relationships. Another limitation is the depth of the analysis of the relationship between the automaker and the SS. Since these relations involve intense information interchange and are assured through contracts, many of them are confidential and could not be revealed. The greatest difficulty was the field data collection, due to the novelty of the theme.

Far from putting an end to the debate on this subject, further research is necessary in order to contribute to a deeper understanding of the partnership relations between automakers and auto parts suppliers, and the local and global configuration of supply chains in the automotive sector. This is even more neces- 
sary due to the increasing importance of the Brazilian plants of subsidiary multinationals in the global context of the automotive industry.

\section{REFERENCES}

ANFAVEA (2008), ANFAVEA (National Association of Motor Vehicle Manufacturers) Letter, Available in: www.anfavea. com.br. Access in: January 20 2008.

AUTOMOTIVE BUSINESS (2005), Nova Anchieta, uma revolução dentro da fábrica pioneira. Available in: www.automotivebusiness.com.br, Access in: February 1st, 2005.

CARVALHO, R. Q. QUEIROZ, S. R. R., HUMPHREY, J., CONSONI, F. L., COSTA, I., \& FONSECA, R. R. (2000) Globalização e reestruturação da cadeia produtiva na indústria automotiva: qual é o papel do Mercosul? Partnership IPEA-DPCT/ IG/UNICAMP. Final Report. FUNCAMP, 252p.

CHIZZOTTI, A. (1995) Pesquisa em ciências humanas e sociais, Second Edition. São Paulo, Cortez.

COOPER, M, LAMBERT, D., \& PAGH, J. (1997), Supply chain management: more than a new name for logistics. The International Journal of Logistics Management, Vol. 8, No. 1, pp. 1-13.

BAUM, J. A. C.; DUTTON, J. E. (1996), The embeddedness of strategy. Advances in Strategic Management, Vol.13. pp. 363-388.

BOYER, R. CHARRON, E., JURGENS, U., TOLLIDAY, S. (1998), Between imitation and innovation: the transfer and hybridization of productive systems in the international automobile industry. New York, Oxford University Press.

CHRISTOPHER, M. (1998) Logistics and Supply Chain Management, London, Prentice Hall.

DORAN, D. (2004), Rethinking the supply chain: an automotive perspective. Supply Chain Management: an International Journal, Vol. 9, No.1, pp.102-109.

FYNES, B.; VOSS, C.; BÚRCA, S. (2005), The impact of supply chain relationship dynamics on manufacturing performance. International Journal of Operations \& Production Management, Vol. 25, No. 1, pp. 6-19.

FRIEDBERG, E.; NEVILLE, J.P. (1999), Inside partnership Trust, opportunism and cooperation in the European automobile industry. In: Grandori, Anna (1999), Interfirm Networks: Organization and Industrial Competitiveness, Routledge Studies in Business Organization and Networks, 11.

GNYAWALI, D.; MADHAVAN, R. (2001), Cooperative networks and competitive dynamics: a structural embeddedness perspective. Academy of Management Review, Vol. 26, No.3, pp. 431-445.

GHOSH, A.; FEDOROWICZ, J. (2008), The role of trust in supply chain governess. Business Process Management Journal; Vol. 14, No. 4.

GULATI, R. (1999) Where do interorganizational networks come from? American Journal of Sociology, Vol.104, No.5, pp. 1439-93.
GULLEDGE, T.; CHAVUSHOLU, T. (2008), Automating the construction of supply chain key performance indicators. Industrial Management \& Data Systems, Vol. 108, No. 6, pp.750 -774 .

HADAYA, P.; CASSIVI, L. (2007), The role of joint collaboration planning actions in a demand-driven supply chain. Industrial Management \& Data Systems, Vol. 107, No.7, pp. 954978.

HUMPHREY, J.; LECLER, Y.; SALERNO, M.S. (2000), Global strategies and local realities: the auto industry in emerging markets. London, Macmillan.

KNIGHT, J. (1998), The bases of cooperation: social norms and rule of law. Journal of Institutional and Theoretical Economics, Vol.154, No. 4, pp. 754-63.

KOUDAL P.; WELLENER, P. (2003), Digital loyalty networks: continuously connecting automakers with their customers and suppliers. Strategy and Leadership, Volume 31, Number 6, pp. 4-11(8). pp.4-11.

LAMBERT, D. M.; COOPER, M.C.; PAGH, J.D. (1998), Supply chain Management: implementation issues and research opportunities. The international Journal of Logistics management, Vol. 9, No.2, pp. 1-19.

LAUER, T. W. (2000), Side effects of mandatory EDI order processing in the automotive supply chain. Business Process Management Journal, Vol. 6, No.5, pp. 366-375.

LEE, C. W.; KWON, I. G.; SEVERANCE, D. (2007), Relationship between supply chain performance and degree of linkage among supplier, internal integration, and customer. Supply Chain Management, Vol.12, No. 6., pp. $444-452$.

LUNG, Y. (2000), Is the rise of emerging countries as automobile producers an irreversible phenomenon? In: HUMPHREY, J.; LECLER, Y.; SALERNO; M.S. Global strategies and local realities: the auto industry in emerging markets. London, Macmillan.

MCCORMACK, K.; LADEIRA, M. B.; OLIVEIRA, M. P. V. (2008) Supply Chain Maturity and Performance in Brazil. Supply Chain Management, Vol.13, p. 272-282.

MCHUNG, M; HUMPHREYS, P; MCLVOR, R. (2003) Buyer-supplier relationships and organizational health. The Journal of Supply Chain Management, Vol.39, No.2, pp.15-25.

MORRIS, D., DONNELLY, T., AND DONNELLY, T. (2004) Suppliers parks in the automotive industry. Supply Chain Management: An International Journal, Vol.9, No.2, pp.129 133.

PIRES, S., CARRETERO DIAZ, L.E. (2007) Gestión de la Cadena de Suministros, McGraw Hill, Madrid, 258p.

PIRES, S. (1998), Managerial implications of the modular consortium model in a Brazilian automotive plant. International Journal of Operations \& Production Management, Vol. 18, No. 3, pp. 221-32.

PODOLNY, J. M. (1994), Market uncertainty and the social character of economic exchange. Administrative Science Quarterly, Vol.39, pp. pp.458-83. 
PRAHINSKI, C., BENTON, W. C. (2004), Supplier evaluation: communication strategies to improve supplier performance. Journal of Operation Management, Vol. 22, pp.39 - 62.

SALERNO, M. S., MARX, R., ZILBOVICIUS, M. (2003), A nova configuração da cadeia de fornecimento na indústria automobilística no Brasil. Revista de Administração -USP , São Paulo, Vol. 38, No. 3, pp. 192-204.

SÁNCHES, A. M., PÉRES, M. P. (2003), The use of EDI for interorganizational co-operation and co-ordination in the supply chain. Integrated Manufacturing Systems, Vol. 14, No.8, pp. $642-651$.

SOOSAY, C. A.; HYLAND, P. W.; FERRER, M. (2008), Supply chain collaboration: capabilities for continuous innovation. Supply Chain Management, Vol. 13, No.2, 160 - 169.
SVENSSON, G. (2001), Perceived trust towards suppliers and customers in supply chain of Swedish automotive industry. International Journal of Physical Distribution \& Logistics Management, Vol. 31, No.9, pp.647-62.

TRIENEKENS, J. (1999), Management of Process in chains: a research framework. Thesis. Wageningen University.

UZZI, B. (1997), Social structure and competition in inter-firm networks: the paradox of embeddedness. Administrative Science Quartely, Vol. 42, pp.35-67.

VOLPATO, G. (2002), Carmakers internationalization strategies: an overview. La Lettre du Gerpisa, No.158, pp. 2-5.

YIN, R. K. (1994), Case study research. California: Sage Publications.

\section{AUTHOR'S BIOGRAPHY}

Mário Sacomano Neto has a Doctorate degree in Production Engineering (UFSCar); He was a Visiting Scholar in University of Chicago (USA). He has a Master's degree in Production Engineering (USP/EESC) and a Bachelor's Degree in Business Administration (PUC). Nowadays, he is an associate professor of Operations, Supply Chain and Network Analysis in Business Administration Mastership at Methodist University of Piracicaba (UNIMEP). Email: msacomano@unimep.br; pmsn@terra.com.br.

Sílvio R. I. Pires has a B.Sc. (UFSCar), and a M.Sc. and a Doctorate degree (EESC-USP) in Production Engineering. He is a full professor of Operations and Supply Chain Management at the Methodist University of Piracicaba (UNIMEP). Formerly he was a Production Planning and Control manager in a large heavy equipments company in Brazil, a visiting research-professor at IMD in Switzerland, and a visiting professor at the Instituto de Empresa Business School in Spain. He also conducted several projects to large companies operating in Brazil. He has 25 years of practical experience in Operations Management. E-mail: sripires@unimep.br 